\title{
International Anti-Corruption Cooperation: Main Features and Trends
}

$\mathrm{Na}$ JIANG*

Associate Professor of Beijing Normal University, College for Criminal Law Science, 100875, P.R. China

\begin{abstract}
In recent years, some changes have taken place with international cooperation against corruption. New changes to the different perspectives of domestic and international research focus on primary aspects: recent developments on the principles of international anti-corruption cooperation, intensive research on the mechanisms for realizing international anti-corruption cooperation, a sudden emergence of anti-corruption education cooperation, the extensive scope and integrated methods of law enforcement cooperation on anti-corruption, new developments to international anti-corruption assistance. This study would be of a very important academic value and practical significance to an accurate grasp of the future trend, a critically learning from the experience of overseas laws and an expansion of the relevant theories on domestic laws.
\end{abstract}

As the most important international anti-corruption body in the world, the International Association of AntiCorruption Authorities (IAACA), held the Fifth Congress in Morocco in October 2011. This non-governmental, non-political, non-profit and judicial international organization tends to promote implementing the UN Convention against Corruption and further international cooperation against corruption and bribery. This study would be of a very important academic value and practical significance to an accurate grasp of the future trend, a critically learning from the experience of overseas laws and an expansion of the relevant theories on domestic laws. The following will focus on the latest developments to the areas of international anti-corruption cooperation from different research perspectives.

\section{Recent Developments on the Principles of International Anti-Corruption Cooperation}

The international cooperation against corruption the Contemporary China has actively promoted mainly concerns the types of crimes such as relating to the escaping corrupt officials, a transfer of assets, and foreign or international public officials' corruption, [1] which thus has an impact on the content and scope of the relevant cooperative principles. Due to the differences in national culture, legal systems and limitations on the treaties of judicial assistance, however, the application of international cooperative principles on anti-corruption encounters many difficulties, including investigation, evidence collection, recovering stolen goods and arresting the perpetrators [2]. Moreover, many legal principles independently formed in national practices may lead to conflict or be detrimental to international cooperation, in the course of applying to the corruption-related crimes. In order to explore the mechanism for solving anti-corruption legal problems, various countries in the process of prosecuting such offenses in recent years have paid more attention to playing the role of the following legal principles:

The first and foremost is the principle of national sovereignty. Sovereignty is the power inherent in a country as the highest internal and independent external ones, specifically containing independence, equality, self-defense and management. Since international anticorruption cooperation is essentially the co-operation among sovereign states, the principle of sovereignty becomes the first that should follow in solving the conflict of laws issues in anti-corruption cooperation. In this regard, the principle of national sovereignty could be mainly demonstrated as the specificity of judicial sovereignty, observance of international treaties, applicability of immunity power and special protection on national interests.

The second is about equality and mutual benefit principles. Multilateral treaties of anti-corruption cooperation in international law are concluded on the basis of equality and mutual benefit principles. Even without international treaties, anti-corruption cooperation or judicial assistance between countries, also require implement the basic principles of equality and mutual benefit. Otherwise, it will be difficult for the relevant international cooperation to be achieved. In the process of international anti-corruption cooperation, equality and mutual benefit principles could be mainly manifested as the equality of main bodies' qualifications, voluntariness of carrying out cooperation on criminal matters, reciprocity of rights and obligations, that of applying national treatment, applicability of State's immunity, equal consultations and reciprocal restrictions.

The third is the principle of dual criminality. It is also known as a double imputation that derives from national sovereignty in international law and refers to a behavior constituting a crime in accordance with the laws of both requesting and requested States. In general, it is necessary for them to rely on the assistance of other countries, if arresting the suspect who fled to other countries for a domestic trial. But obtaining of overseas support and assistance is conditioned with a respect for other countries' laws and public order, which just reflects a manifestation of respecting national sovereignty [3]. Consequently, the principle of double criminality has a very important protective function on the requested State and plays the role of the safety valve for sovereign states. This is also the case for China where criminal law is relatively loose and principled without a fine system concerned, in a comparison with that in some developed countries [4]. In dealing with the conflict of laws against corruption, therefore, an adherence to this principle is more conducive to safeguarding national sovereignty and legal authority.

*Corresponding author: Na JIANG, Associate Professor of Beijing Normal University, College for Criminal Law Science, 100875, P.R. China, Tel: + 8610 5880 6183; E-mail: na.jiang@bnu.edu.cn

Received June 04, 2014; Accepted July 25, 2014; Published August 01, 2014

Citation: JIANG N (2014) International Anti-Corruption Cooperation: Main Features and Trends. Intel Prop Rights 2: 121. doi:10.4172/2375-4516.1000121

Copyright: (c) 2014 JIANG N. This is an open-access article distributed under the terms of the Creative Commons Attribution License, which permits unrestricted use, distribution, and reproduction in any medium, provided the original author and source are credited. 
The fourth is bis in idem principle. In the process of implementing the Convention against Corruption, a series of basic human rights should be subject to special attention and good protection. For example, Article 14(7) of the International Covenant on Civil and Political Rights that China has signed, providing that "No one shall be liable to be tried or punished again for an offence for which he has already been finally convicted or acquitted in accordance with the law and penal procedure of each country", means that effective criminal judgments shall not be prosecuted or tried again. Accordingly, this principle has been established as a basic international norm in criminal justice, [5] in an attempt to highlighting the effect of judgments, avoiding new wrongful convictions in litigation and thus achieving protection on human rights.

In the aspects of research scope and academic significance, the basic principles of international anti-corruption cooperation have made significant progress in contemporary times than that in the past. Firstly, both connotation and extension of the relevant principles is no longer just knowledge in legal concepts, but also that remains to be clarified in the theoretical context of political science, international relations or other social sciences. Secondly, the domestic criminalization of international crimes has become the key issues of international law theories on and international criminal norms of anti-corruption cooperation laws among diverse countries in recent years. It not only abandoned exploring into the relationship between international and domestic laws in the teachings of science, but also takes it as an explaining rather than theoretical concept, pursuing the doctrine of interpretation of the law as a whole. Its integrity emphasizes on legal doctrines in international criminal law, as well as requiring a comprehensive consideration of political, moral and other factors. In theory, it is designed to building a practical system through analyzing the significance of pluralistic politics for legal principles, including international human rights and extradition theories as the core and key of the relevant legal concepts in understanding the principles of international anti-corruption cooperation. It can be said that a series of international anti-corruption meetings in last year clearly reflects the new trends of changing principles, around which an exploration of these principles has demonstrated the collusion between progress on the global rule of law and international anti-corruption cooperation in value.

\section{Intensive Research on the Mechanisms for Realizing International Anti-Corruption Cooperation}

Intensive research on the mechanisms for realizing international anti-corruption cooperation has developed into the focus of contemporary research on international anti-corruption. In the third seminar of the IAACA, there has been a special address on strengthening the exchange of national anti-corruption law enforcement agencies to improve the level of international cooperation against corruption. Later, in the fourth seminar, the delegation adhered to and updated the claims on seeking after multi-channel, multi-form mechanisms for anti-corruption cooperation in keynote speeches. In fact, inquiries into the mechanism for achieving international cooperation against corruption follows the first seminar, without standing still but moving forward in reflection and exploration.

As a party to the UN Convention against Corruption (UN Convention), China has widely carried out a series of anti-corruption activities on its international cooperation, and gradually expanded an in-depth study of its implementation mechanisms. Currently, scholars put forward such diverse opinions as the doctrines of bis in idem, national consultations, exclusive jurisdiction and close relations, of which some are reasonable but still remain certain misunderstandings in theory not to cope with practical obstacles concerned [6]. Nevertheless, academic and practical groups have reached the following agreement on mechanisms for its realization as a whole. Concerning the legislative means, they mainly include an active signing or accession to various international anti-corruption instruments, strengthening negotiation and formulation of bilateral treaties on controlling corruption crimes with other countries, particularly the economically developed ones, improving the domestic legislation governing corruption crimes to promote transformation and implementation of anti-corruption treaties in the relevant laws and regulations of China. This will be helpful to perfecting anti-corruption criminal laws, combating corruption crimes in a timely and efficient approach, and introducing appropriate complementary measures to build a specification system of the three-dimensional systems against corruption [7].

With regard to the access to justice, it involves four primary aspects as follows: The first is to clarify the functional agencies responsible for such cooperation. From judicial cooperation treaties that China has signed, Chinese authorities responsible for criminal judicial cooperation contain such departments as the Ministry of Foreign Affairs, Ministry of Justice, Supreme People's Court and Procuratorate (SPP), albeit without clear functions. According to the Criminal Procedural Law of the PRC, the People's Procuratorates are in charge of investigation into corruption crimes, and in judicial practice they have played an active role and accumulated rich experience in criminal judicial cooperation against such crimes. Therefore, it might as well that the SPP shall be regulated as the sole functional authority responsible for judicial cooperation on such crimes. The second is to increase the content of international cooperation against corruption. China considers further expanding the scope of international anti-corruption cooperation, in a mutual cooperation with other countries on corruption cases. It aims to pay more attention to the other forms of international judicial cooperation, such as transferring of criminal proceedings, handover of the sentenced and so on. The third is to expand the areas of cooperation. Apart from strengthening of the control on the judicial cooperation of such crimes, it is also required of a mutual assistance in investigation and prosecution of civil and administrative cases, in order to build a comprehensive system of international cooperation against corruption crimes. From the practice of international judicial cooperation against corruption, the greatest benefits of asset recovery achieved through civil litigation is a lower standard of proof required. In countries where criminal confiscation of property is not permissible, it is through civil cases to obtain the relevant reliefs, without any prosecution or criminal conviction [8]. The fourth is to expand the channels of international anti-corruption cooperation. For strengthening the efforts on fighting against corruption crimes, China should take a flexible strategy as far as possible under the premise of safeguarding sovereignty and legal authority, to extend means for realizing such cooperation and improving its successful rate.

In addition, other means of implementing mechanisms relate to three primary points: The first is the systems of professional training and departmental consultation. Control on corruption crimes is a systematic and complex social project that requires appropriate expertise and the relevant departments' close coordination and overall collaboration. Hence, it is necessary in current to train professionals in the related fields with knowledge in the rule of law and establish a mechanism for a close consultation among departments [9]. The second is mechanisms for sharing intelligence and resources. In the face of the increasingly rampant corruption crimes, China should pay due attention to the sharing mechanism of international anti-corruption 
information and resources, and take effective measures to cooperate with international organizations to further improve this mechanism. The third is exchanges of and cooperation on the aspects of theoretical research, techniques and experience. Since anti-corruption has become a global issue [10], China should actively strengthen such international exchanges to grasp the relevant information and research dynamic, draw on extensive experience from other countries and better take the serious challenge of anti-corruption cooperation.

\section{A Sudden Emergence of Anti-Corruption Education Cooperation}

The expert group meetings of Anti-corruption Academic Material Initiative, organized by the UNODC in Boston of the USA and then Marrakech of Morocco in 2011, attempted to change traditional anticorruption education and solve problems in international cooperation concerned [11]. From them, there have been certain new thinking that could be mainly demonstrated as follows: The one is an emphasis on the research path of bottom-up from graduate students as the social bottom, which has changed the traditional research perspective of international anti-corruption education, featured with an over concern about the elite level from top-down angle of view. The other is an optimistic attitude towards prospects for developing international cooperation on anti-corruption education, namely, recognizing the loopholes and shortcomings of legal education without losing confidence in or ignoring positive reforms on legal justice concerned. This is a path between idealism and skepticism, with an emphasis on diversified and integrated research methods, in particular, the legal, environmental and cultural interaction, and an empirical analysis based on anti-corruption practices in different areas. It is not limited to the practical effect of formal legal sources on anti-corruption cooperation, but involved in all aspects of social life, showing the diverse and bottom trend of main bodies against corruption and educated objects. For example, more attention on anti-corruption legal education has been paid than the traditional model of international education cooperation, so as to emphasize that legal education should reflect social and economic backgrounds in real and actual legal practice. This would be beneficial to deepening and expanding a comprehensive study of correction on anti-corruption academic materials, and to providing intellectual support as favorable conditions for smoothly pushing forward pilot work on such education and innovation of cooperative ways.

As a whole, the anti-corruption education of the USA and Europe takes the lead in the world, such as some educational institutions of or international organizations in the UK, US and Germany and other developed countries. They use a variety of teaching methods in different practical departments and extensively develop training activities on such thematic courses within their territory, along with gradually applying their training programs to the important sectors of other countries plagued with corruption. In comparison, the process of anti-corruption education in Asian and African countries lags behind the expectations, especially the training courses of initiatively promoting international anti-corruption topics, with a late start and dissatisfying degree and level of development. Among them, anticorruption education in Japan is basically an exogenous type, due to the large dependence on training programs from such organizations as the International Bar Association; but Malaysia differs because of the main source independent from international organizations. Thus, it was basically agreed to upgrade such technical targets as anti-corruption skills and operational capacities to play a dual role of administration persons as both administrator and supervisor, for developing efficient anti-corruption administrative staff or professional managers. Furthermore, a series of anti-corruption courses or comprehensive training should include the content of anti-corruption in required courses as the essential character and qualities of a manager in order to cultivate the talents specialized in anti-corruption. In other words, it requires not only a topic of anti-corruption content courses, but also introduces special knowledge in anti-corruption to the teaching of other courses. For example, concerning company notes in anti-corruption themes, some typical anti-corruption cases in the field of criminal or civil laws might be a starting point, apart from a detailed interpretation on the basic theory and operating practices of such notes. Also, it might as well regard such offenses' harmful consequences and legal responsibilities as the main clues throughout a systematic exploration into a complete picture of laws and regulations on corruption issues.

Specifically to China, without a specialized course of anticorruption, the relevant anti-corruption education still exist for a long time, such as the public servants' education concerned in local Party colleges, relevant courses for legal or economic graduates in universities and so on. Some law schools has increased anti-corruption contents in the currently taught courses for graduate education, in such forms of extending the class of anti-corruption topics, frequently organizing students to develop academic conferences and other anticorruption activities, as well as teaching a new course titled with UN anti-corruption topics for regular law education. However, anticorruption education in contemporary China concerns more about its prevention in public areas than such phenomenon in the private sphere, which obviously does not meet the practical needs of international anti-corruption cooperation. In this regard, the preliminary anticorruption curriculum topics and basic annotation on the target groups of sub-headings has been listed in the phase of substantive debate on the subject menu, at the first expert group meeting. On this basis, the second meeting revised the menu in draft, emphasizing the focus and importance of substantive debates in international education cooperation, including fresh knowledge drawn from new participants to reorganize curriculum topics for certain courses. A critical analysis of them basically revolves around such controversy issues as the definition of anti-corruption, crimes on corruption, its governance, preventive measures and control modes, range of its legal sources and international cooperation on asset recovery concerned.

\section{The Extensive Scope and Integrated Methods of Law Enforcement Cooperation on Anti-Corruption}

In recent years, with the advancement of international cooperation on law enforcement against corruption, research on the relevant anticorruption cooperation is increasingly deepening. This could be mainly illustrated from diverse research objects, intensive anti-corruption cooperation and the expanding trend of methodology.

Specifically, the widening of research objects has extended to such detailed issues on the facts and techniques of such cooperation, namely from an examination on the basic aspects of national anti-corruption legal systems, to a new exploration into the functions and power configuration of anti-corruption law enforcement agencies. Despite that scholars advocate for many conflict resolution means on law enforcement cooperation, the pragmatic cooperation on international anti-corruption is particularly necessary with the continuous spread of transnational organized crimes of corruption. In practice, a full play of the IAACA's platform role aims at establishing more effective international mechanisms for anti-corruption cooperation. It lies in the fact that a close cooperation with the relevant international 
organizations and expansive areas on anti-corruption law enforcement among states would help solve such practical problems of law enforcement cooperation as extradition and repatriation of the criminal suspects, recovering and returning money or property involved, and exchanges of information on such crimes. These efforts have been partly made in an attempt to eliminate the safe haven of corrupt officials and enhance the joint strengths of preventing anti-corruption cooperation on law enforcement [12].

Another convincing aspect relates to refinement of case types. The cases within the scope of international cooperation on anti-corruption law enforcement have extended from economic cases to all types of corruption cases, including transnational organized or network-based crimes of corruption. Moreover, as for law enforcement cooperation on new types of corruption crimes, it is requisite for us to make a specific analysis of connecting factors in corruption crimes, and thus find the most closely associated country with the final exercise of criminal jurisdiction. If it is unwilling or unable to exercise its jurisdiction, the relatively close countries, such as those countries where crimes committed, as the defendants' nationality, with evidence of the injured or stolen goods and so on, are expected to exercise the enforcement jurisdiction of such crimes.

The third point is about the options of educational texts, which have changed from the immediate text to a unified amendment to international instruments. In the relevant expert group meetings, experts have an analysis of national anti-corruption textbooks and criticism of social effects on the relevant national policies in application, and then pointed out the relations of training programs on international anti-corruption education. This will undoubtedly be helpful to a better realization of international anti-corruption cooperation, even if some scholars only stressed the necessity of special education in international anti-corruption or significant effects on general education, but others maintains a balance. From intention of international drafts, the joint approach of both educations would benefit collecting information on feedback of international anti-corruption academic initiatives, further inquiring more proposals and promoting a wide application or development on them.

The fourth concerns the diversity of analytical methods. A formal or model analysis of international anti-corruption cooperation is no longer the only way, with an emergence of a new method of fusing values inside. For example, concerning the way of filling in the gap among jurisdictions in conflict, it is important on the basis of the most closely linked value, to judge the order of jurisdictional countries in face of several choices with the same number of linkage with crimes. It might as well regard those countries where crimes committed as the closest one for exercising its jurisdiction, considering the priority of jurisdiction in the principle of sovereignty over territory. Another instance is the value basis of the interaction between specialized training and general education, in the various stages of the anti-corruption education for graduate students. Hence, it may be appropriate to expand a depth study on a series of problems, such as corruption origins, the law of its development and coping strategies, the general regulations and special responsibilities of international treaties, in teaching of thematic contents on the related fields.

\section{Reference}

1. Xia S, Hongping G (2007) how deep is the black hole of the escaping Chinese corrupt officials.

2. Haibo W (2008) Shenzhen is planning to build new institutions on investigating into foreign corruption cases and arresting corrupt officials.

3. Yu Z (2008) Research on Anti-Corruption International Criminal Judicia Assistance, 2 Jianghuai Forums.

4. Feng $\mathrm{H}$ (2007) new developments on the criminal systems of international judicial assistance, Contemporary Law 6.

5. Zhihui Z (2002) International Criminal Law Studies, Fangzheng Publishing House of China.

6. Haiying $L$ (2009) Research on the conflicted Issues of criminal jurisdictions over Foreign Corrupt cases: A thinking from the Chinese Perspective, 3 Contemporary Laws.

7. Hengshan S (2006) Outline of Perfecting and improving China's anti-corruption legal systems: A perspective from the UN Convention against Corruption, Social Sciences Journal of Jilin University 3.

8. Yuguan $Y$ (2007) Research on anti-corruption international criminal justice cooperation, 3 Procuratorate Daily.

9. Bensheng G, Piying $F$ (2008) The need of studying foreign legal systems to cope with refurbished means where corrupt officials escape abroad.

10. Yong G (2004) to strengthen international cooperation on combating transnational corruption, 5 International Studies.

11. UNODC (2011) Summary of ACAM initiative Boston meeting.

12. Yongkang $Z$ (2011) To strengthen the exchanges of national anti-corruption law enforcement agencies to continuously improve the level of international cooperation against corruption. 